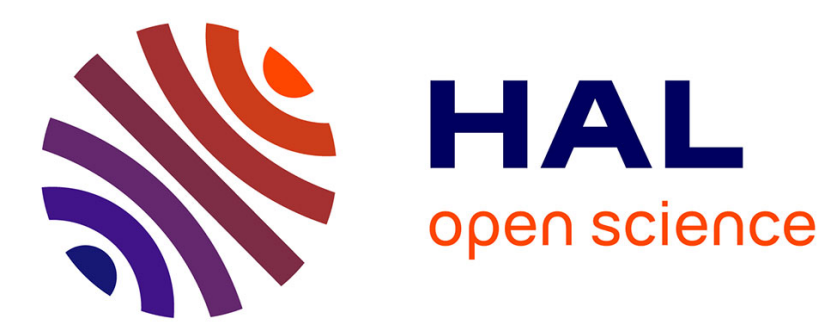

\title{
Enhanced Activation of Coordinated Dinitrogen with p-Block Lewis Acids
}

\author{
Antoine Simonneau, Michel Etienne
}

\section{To cite this version:}

Antoine Simonneau, Michel Etienne. Enhanced Activation of Coordinated Dinitrogen with p-Block Lewis Acids. Chemistry - A European Journal, 2018, 24 (48), pp.12458-12463. hal-01829681

\section{HAL Id: hal-01829681 \\ https://hal.science/hal-01829681}

Submitted on 4 Jul 2018

HAL is a multi-disciplinary open access archive for the deposit and dissemination of scientific research documents, whether they are published or not. The documents may come from teaching and research institutions in France or abroad, or from public or private research centers.
L'archive ouverte pluridisciplinaire HAL, est destinée au dépôt et à la diffusion de documents scientifiques de niveau recherche, publiés ou non, émanant des établissements d'enseignement et de recherche français ou étrangers, des laboratoires publics ou privés. 


\title{
Enhanced Activation of Coordinated Dinitrogen with p-Block Lewis Acids
}

\author{
Antoine Simonneau, ${ }^{*[a, b]}$ and Michel Etienne ${ }^{[a, b]}$ \\ LCC, Université de Toulouse, CNRS, UPS; 205, route de Narbonne, BP44099, F-31077 Toulouse Cedex 4, France. \\ E-mail: antoine.simonneau@lcc-toulouse.fr \\ Homepage: https://www.lcc-toulouse.fr/
}

In memory of Dr. Julien Louvel

\begin{abstract}
This Concept article highlights recent research on Lewis acid adducts of dinitrogen complexes, including our contributions. After a reminder of the early works, it is demonstrated that such kind of species offers a new platform for dinitrogen functionalization as well as valuable models for the understanding of elementary steps of (bio)catalytic cycles. When possible, parallels regarding this mode of activation from the orbital point of view are drawn between the different systems discussed herein.
\end{abstract}

Keywords: dinitrogen complexes $\bullet$ Lewis acids $・ p$-block $•$ dinitrogen functionalization $\cdot$ Frustrated Lewis Pairs

\section{Introduction}

Molecular dinitrogen complexes have been the focus of intensive studies since the mid 1960s when Allen and Senoff disclosed the first coordination compound exhibiting an end-on coordinated $\mathrm{N}_{2}$ unit (Figure 1, left). ${ }^{[1]}$ Chemists immediately realized the potential of such entities as a platform to study chemical transformations of the abundant, but very stable and inert $\mathrm{N}_{2}$ molecule. At the advent of this chemistry, the reactivity of these complexes with Brønsted acids was intensively investigated. ${ }^{\left[{ }^{[2]}\right.}$ These studies offered simplified models of the reactions occurring at the active site of the nitrogenases (Figure 1, right), i.e. the successive transfers of protons and electrons to the FeMo cofactor necessary for $\mathrm{N}_{2}$ reduction. At the same time, these investigations paved the way for the development of catalysts for ammonia synthesis that could potentially operate under ordinary pressure and temperature conditions. ${ }^{[3]}$ The synthesis of organonitrogen compounds also fueled interest in the coordination chemistry community. ${ }^{[4]}$ Having an estimate of the Brønsted or Lewis basicity of the $\mathrm{N}_{2}$ ligand appeared to be important for the conception of the above-mentioned reactions. The preparation and characterization of Lewis acid (LA) adducts of dinitrogen complexes was therefore envisaged as a valuable source of information, since it would allow one to judge whether the $\mathrm{N}_{2}$ ligand is accessible to electrophiles in general, and what response the transition metal center would give upon complexation of the Lewis acid in terms of $d \rightarrow \pi^{*}$ electron back donation. Here, key analytical probes are typically the $\mathrm{N}-\mathrm{N}$ bond stretching frequency $v_{\mathrm{NN}}$ in IR spectroscopy, or metrical parameters from X-ray diffraction studies. Recently, some research groups have revisited combinations of end-on dinitrogen phosphine complexes with p-block Lewis acids. This has allowed for the preparation of models of elusive species relevant to catalytic dinitrogen reduction processes, as well as the discovery of unprecedented reactivity patterns, thus giving a new momentum toward the study of this class of coordination compounds. 

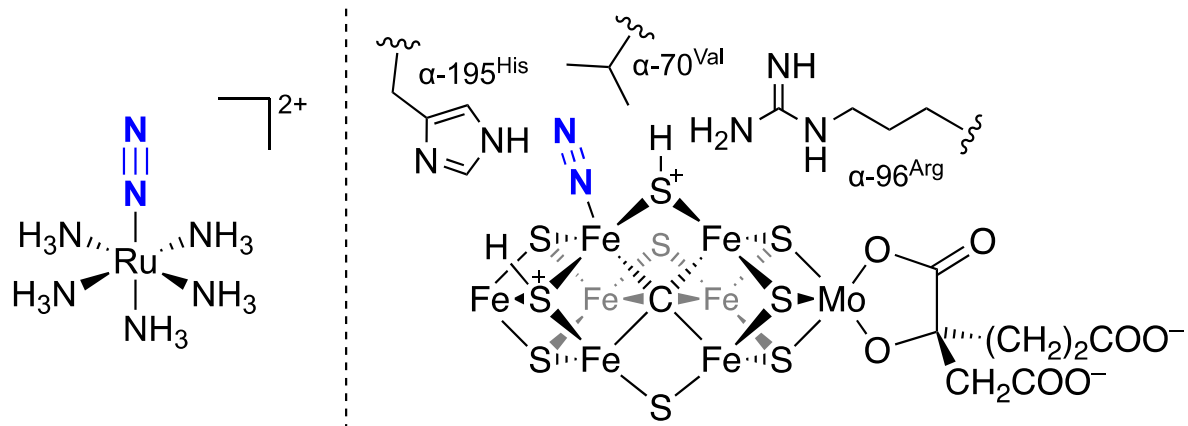

Figure 1. First reported $\mathrm{N}_{2}$ complex (left) and the active site of the nitrogenase showing $\mathrm{N}_{2}$ bound to the FeMo cofactor (right).

\section{Early Works}

While the nitrogenases had been known for decades when Allen and Senoff made their discovery, knowledge about their mechanism was not as advanced as it is today. ${ }^{[5]}$ As they were already known to have a bimetallic nature, Chatt and his colleagues at the Nitrogen Fixation Unit of the University of Sussex examined the interaction of some end-on dinitrogen complexes with electrophilic transition metal or main-group compounds in order to get some insights into the mechanism of nitrogen fixing metalloenzymes. ${ }^{[6]}$ They could prepare and characterize a series of heterobimetallic complexes for which they proposed a structure featuring an $N_{2}$ ligand bridging two metals in a $\eta^{1}: \eta^{1}$ fashion, as a result of Lewis acid-Lewis base (LB) interaction. In some instances (e.g. with $\mathrm{TiF}_{4}, \mathrm{TiCl}_{4}, \mathrm{FeCl}_{3}, \mathrm{CuCl}$ or $\mathrm{PF}_{5}$ ), these reactions failed to produce a stable $\mathrm{N}_{2}$-bridged complex and resulted in oxidation of the starting $\mathrm{N}_{2}$ complex. ${ }^{[6 \mathrm{~b}, \mathrm{c}]}$ The reactions of isoelectronic group 6-8 dinitrogen phosphine complexes with different aluminum compounds $\left(\mathrm{AlMe}_{3}, \mathrm{AIPh}_{3}\right.$ and $\left.\mathrm{AlCl}_{3}\right)$ were investigated and the isolated adducts, when viable, were characterized by ${ }^{1} \mathrm{H}$ NMR and IR spectroscopy. ${ }^{[6, f]}$ Although the complexes investigated $[\mathrm{Mo}(0), \mathrm{W}(0), \operatorname{Re}(\mathrm{I})$ and $\mathrm{Os}(\mathrm{II})]$ formed stable 1:1 adducts with $\mathrm{AlMe}_{3}$ without noticeable amounts of alkylated products (Scheme 1, adduct formation between the Mo complex $\mathbf{1}$ and $\mathrm{AlMe}_{3}$ ), the reaction with $\mathrm{AlPh}_{3}$ was of narrower scope, while treatment with $\mathrm{AlCl}_{3}$ generally resulted in decomposition along with $\mathrm{N}_{2}$ evolution. ${ }^{[7]}$ Correlation between $d$ electron delocalization from the metal center into the $\pi^{*}$ molecular orbital $(\mathrm{MO})$ of the $\mathrm{N}_{2}$ ligand and basicity of its $\beta$ nitrogen was experimentally established. The weakening of the $\mathrm{N}-\mathrm{N}$ triple bond observed by IR spectroscopy was attributed to a "push-pull" mechanism where electron density withdrawal on one side of the bridging $\mathrm{N}_{2}$ ligand triggers enhanced $d \rightarrow \pi^{*}$ back donation from the transition metal center. ${ }^{[a, b]}$

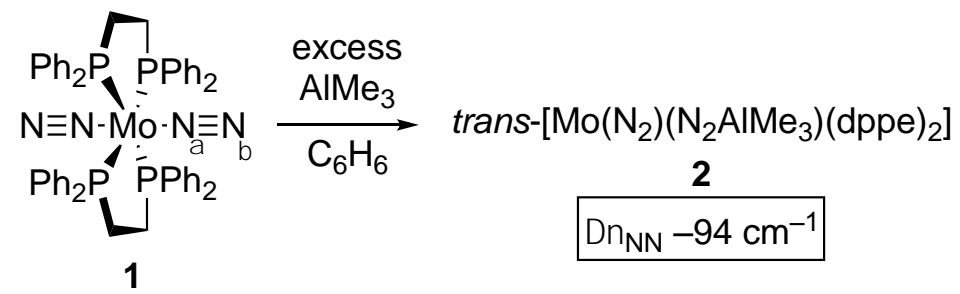

Scheme 1. Adduct of a $\mathrm{N}_{2}$ complex with an aluminum Lewis acid.

\section{Adducts with a Side-On, End-On $\mathrm{N}_{2}$ Complex}

The late 1990s and early 2000s witnessed major breakthroughs in the chemistry of molecular dinitrogen complexes: $\mathrm{N}_{2}$ cleavage by low-coordinate, well-defined Mo complexes: ${ }^{[8]}$ the achievement of catalytic ammonia synthesis, ${ }^{[9]}$ albeit with limited turn-over numbers and turn-over frequencies; and hydrogenation of coordinated $\mathrm{N}_{2}{ }^{[10]}$ the latter becoming possible with the discovery of the side-on coordination mode in homobimetallic complexes. ${ }^{[11]}$ Remarkably, all these processes occurred in 
especially mild conditions. In 2005, a joint study on the interaction of the Ta complex $\left[\{(\mathrm{NPN}) \mathrm{Ta}\}_{2}(\mu-\right.$ $\mathrm{H})_{2}\left(\mu-\eta^{1}: \eta^{2}-\mathrm{N}_{2}\right)$ ] (3), with various $\mathrm{p}$-block LA [AIMe $3 \mathrm{GaMe}_{3}$ (both not shown) and $\mathrm{B}\left(\mathrm{C}_{6} \mathrm{~F}_{5}\right)_{3}$, Scheme $2]^{[12]}$ by Tuczek, Fryzuk and coworkers sporadically brought back into fashion group 13 LA adducts of $\mathrm{N}_{2}$ complexes. The goal of this investigation was to better apprehend the reactivity of the $\mathrm{N}_{2}$ ligand in the rare side-on, end-on coordination mode. ${ }^{[13]}$ LA addition to complex 3 occurred at the $\beta$ nitrogen to give 4. A bathochromic shift of the $v_{\mathrm{NN}}$ stretch $\left(-20 \mathrm{~cm}^{-1}\right)$ in the IR spectrum was evidence of further weakening of the $\mathrm{N}-\mathrm{N}$ bond in 4 . The bonding situation in a model complex, $\left[\left\{\mathrm{PH}_{3}\left(\mathrm{NH}_{2}\right)_{2} \mathrm{Ta}\right\}_{2}(\mu-\mathrm{H})_{2}(\mu-\right.$ $\left.\left.\eta^{1}: \eta^{2}-\mathrm{N}_{2}-\mathrm{BH}_{3}\right)\right]$, was investigated by means of DFT calculations. Boron complexation leads to a decrease of the HOMO's energy. ${ }^{[14]}$ Although the overall symmetry is different than that in the end-on mononuclear complexes, the HOMO also corresponds to a bonding interaction of the metal centers' filled $d \pi$ orbitals with antibonding $\pi^{*}$ of the dinitrogen ligand. Increased $\mathrm{N}_{2}$ polarization can be traced according to Natural Charges (NCs) resulting from a Natural Population Analysis (NPA). The MOs involved in the N-B dative bond are principally a hybrid of the $p_{\sigma}$ and a $\pi$ bond of the $\mathrm{N}_{2}$ fragment and the empty $p$ orbital at boron.

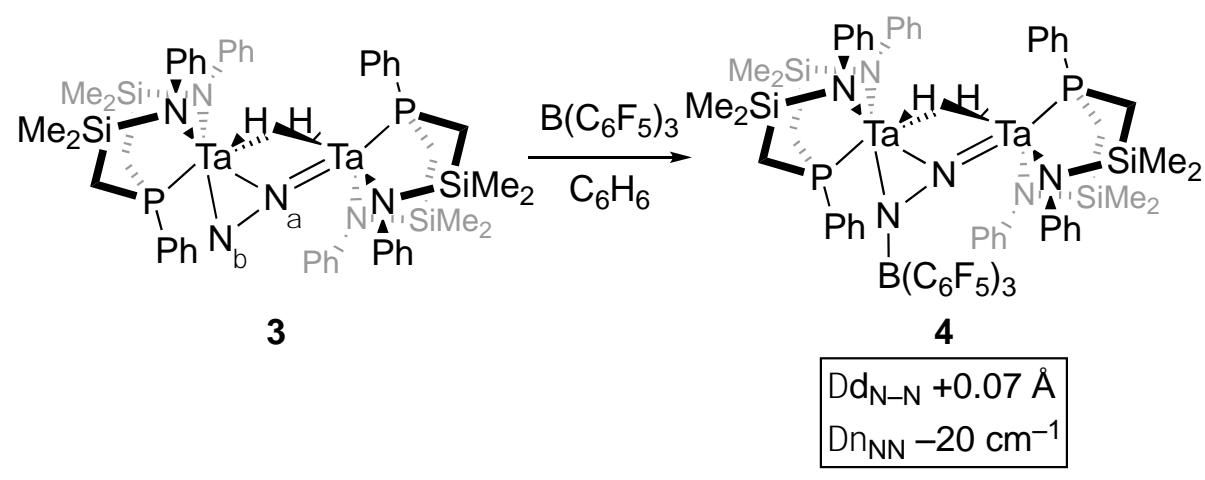

Scheme 2. Adduct of a side-on, end-on (NPN)Ta complex with $B\left(C_{6} F_{5}\right)_{3}$.

\section{Adducts between Iron- $\mathrm{N}_{2}$ Complexes and Strong Lewis Acids for the Understanding of Catalytic Processes}

Very recently, the team of Szymczak investigated the spectroscopic and electrochemical properties as well as electronic structures of adducts between the end-on iron-dinitrogen complex [ $\mathrm{Fe}(\mathrm{depe})_{2}\left(\mathrm{~N}_{2}\right)$ ] (5, depe $=1,2$-bis(diethylphosphino)ethane) and various LAs. The idea was to test the "push-pull hypothesis" by which acidic residues in the active site of the nitrogenase pull electron density from the reduced iron center onto the $\mathrm{N}_{2}$ ligand (see Figure 1), ${ }^{[5]}$ thus rendering it more reactive towards protonation (Scheme 3). ${ }^{[15]}$ In adducts of the type [(depe) $\left.{ }_{2} \mathrm{Fe}\left(\eta^{1}: \eta^{1}-\mathrm{N}_{2}-\mathrm{BR}_{3}\right)\right]\left(\mathrm{R}=2,6-\mathrm{F}_{2} \mathrm{C}_{6} \mathrm{H}_{3}, 2,4,6\right.$ $\mathrm{F}_{3} \mathrm{C}_{6} \mathrm{H}_{2}, \mathrm{C}_{6} \mathrm{~F}_{5}, \mathrm{OC}_{6} \mathrm{~F}_{5}$ or $\mathrm{F}$ ), a good correlation was found between the Lewis acidity of the boranes ${ }^{[16]}$ and the activation of the $\mathrm{N}_{2}$ ligand, as judged by the $v_{\mathrm{NN}}$ stretching frequency in IR spectroscopy. Solid-state (X-ray) and electronic (DFT) structures were reported for the $B\left(C_{6} F_{5}\right)_{3}$ adduct 6 . The NNB arrangement is bent $\left[137.0(3)^{\circ}\right]$, as a result of $p_{B} / \pi^{*}{ }_{N 2}$ mixing for the formation of the $\mathrm{B}-\mathrm{N}$ dative bond. Activation of the $\mathrm{N}-\mathrm{N}$ bond (elongation by $+0.04 \AA$ and $v_{\mathrm{NN}}$ red shift of $126 \mathrm{~cm}^{-1}$ ) upon LA complexation was explained, in terms of orbital considerations, by (i) a greater stabilization of the HOMO, which consists of a combination of d orbitals with the $\pi^{*}$ of $N_{2}$, and (ii) an increase of its $\pi^{*}$ character, analogous to 4. NCs calculations clearly indicate enhanced polarization of the $\mathrm{N}_{2}$ ligand, with an increase of the negative charge at the terminal $\mathrm{N}$. This is counterintuitive, as one would have expected the acceptor to quench its basicity. An important implication of these observations is that transfer of electron density from the metal favors reactivity of electrophiles at the $\mathrm{N}_{2}$ ligand instead of the reduced iron center. This assumption was clearly verified by the protonation of 6 with $\operatorname{HBAr}_{4}{ }_{4}\left(\operatorname{Ar}^{F}\right.$ $\left.=3,5-\left(\mathrm{F}_{3} \mathrm{C}\right)_{2} \mathrm{C}_{6} \mathrm{H}_{3}\right)$ which smoothly occurred at the terminal $\mathrm{N}$ to give 7 in excellent yield (Scheme 3, 6 $\rightarrow 7)$. 


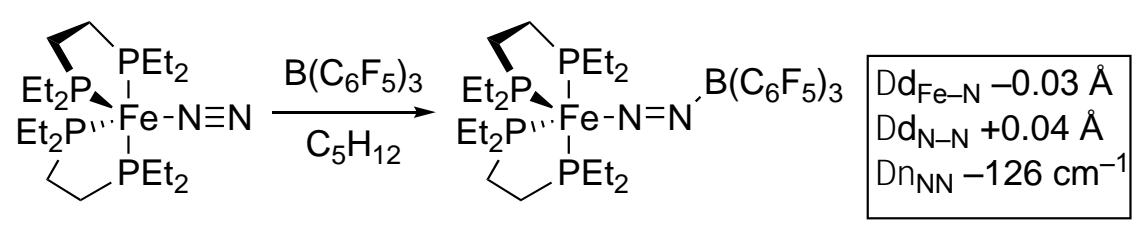

5<smiles></smiles>

no $\mathrm{N}$ protonation

\section{6}

$\downarrow \operatorname{HBAr}_{4} \cdot\left(\mathrm{OEt}_{2}\right)_{2}$

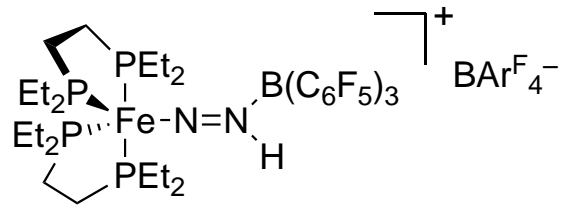

7

Scheme 3. A Lewis acid adduct of an iron- $\mathrm{N}_{2}$ complex aimed at verifying the "push-pull hypothesis" regarding the active site of the nitrogenase.

Beyond validating the "push-pull hypothesis", characterization of such mono-protonated species offers a snapshot of what may resemble elusive $\mathrm{FeN}_{2} \mathrm{H}$ intermediates in catalytic $\mathrm{N}_{2}$ reductions. ${ }^{[3 b, 17]}$ Ashley and coworkers cleverly made use of the more Lewis acidic $\mathrm{Me}_{3} \mathrm{Si}^{+}$silylium ion as a proton mimic to characterize the first cationic silyldiazenido iron complexes (Scheme 4) ${ }^{[18]}$ Treatment of 5 or [Fe(dmpe $\left.)_{2}\left(\mathrm{~N}_{2}\right)\right]\left(8, \mathrm{dmpe}=1,2\right.$-bis(dimethylphosphino)ethane) with $\mathrm{Me}_{3} \mathrm{SiCl} / \mathrm{KBAr}^{\mathrm{F}}{ }_{4}$ afforded the ionic compounds 9 and 10 bearing a bent NNSi arrangement $\left[\mathrm{Ar}^{\mathrm{F}}=3,5-\left(\mathrm{CF}_{3}\right)_{2} \mathrm{C}_{6} \mathrm{H}_{3}\right]$. IR data were in line with a notable weakening of the $\mathrm{N}-\mathrm{N}$ bond. As expected with the stronger $\mathrm{LA} \mathrm{Me}_{3} \mathrm{Si}^{+}$, the $v_{\mathrm{NN}}$ shifted towards lower energies $\left(-224 \mathrm{~cm}^{-1}\right)$ as the consequence of a greater "pull" effect. The X-ray diffraction structures of complexes 9 and 10 show an elongation of the $\mathrm{N}-\mathrm{N}$ bond of ca. $+0.05 \AA$, while the $\mathrm{Fe}-\mathrm{N}$ bond displays greater double bond character than in $\mathbf{5}$ or $\mathbf{8}$. DFT calculations performed on the silyldiazenido complexes were in line with those run by Szymczak and co-workers (vide supra). According to their diamagnetic character, trigonal bipyramid geometry and d orbital-centered HOMOs, the complexes were best described as being $\mathrm{Fe}(0), d^{8}$, rather than $\mathrm{Fe}(\mathrm{II})$, high spin $\mathrm{d}^{6}$. Relevance to the intermediates in catalytic cycles of $\mathrm{N}_{2}$ reduction to silylamines ${ }^{[19]}$ can also be invoked here. Indeed, several silyldiazenido complexes have been reported prior to Ashley's work. Such compounds were obtained by substitution of a (pseudo-)halide in $\mathrm{R}_{3} \mathrm{SiX}$ compounds, ${ }^{[20]}$ and occurrence of $\mathrm{R}_{3} \mathrm{Si}^{+}$cations is rather unlikely. ${ }^{[21]}$

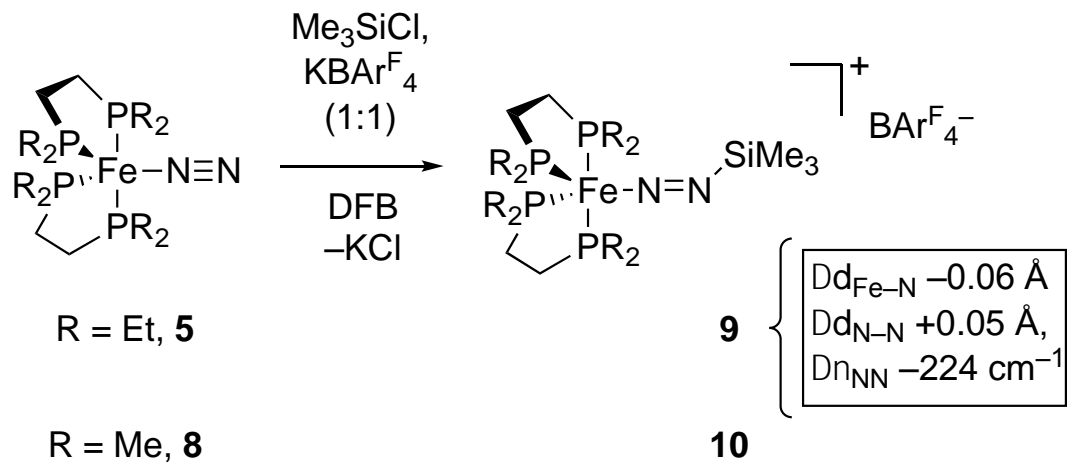

Scheme 4. A cationic Fe-silyldiazenido complex mimics intermediates of catalytic $\mathrm{N}_{2}$ reduction. 


\section{Lewis Acid Adducts of $\mathrm{N}_{2}$ Complexes and the Frustrated Lewis Pair Chemistry}

The "push-pull" paradigm for $\mathrm{N}_{2}$ activation illustrated by the two previous examples can be extended to the recent chemistry of the frustrated Lewis pairs (FLP). ${ }^{[22]}$ This now mature field exploits the simultaneous action of a LA and a Lewis base (LB) - prevented from forming a classical LA-LB adduct by steric interactions - for the activation of a vast array of (small) molecules (see scheme 5, top; activation of $\mathrm{CO}$, isoelectronic to $\mathrm{N}_{2}$, by an intramolecular P/B FLP $\left.{ }^{[23]}\right)$.
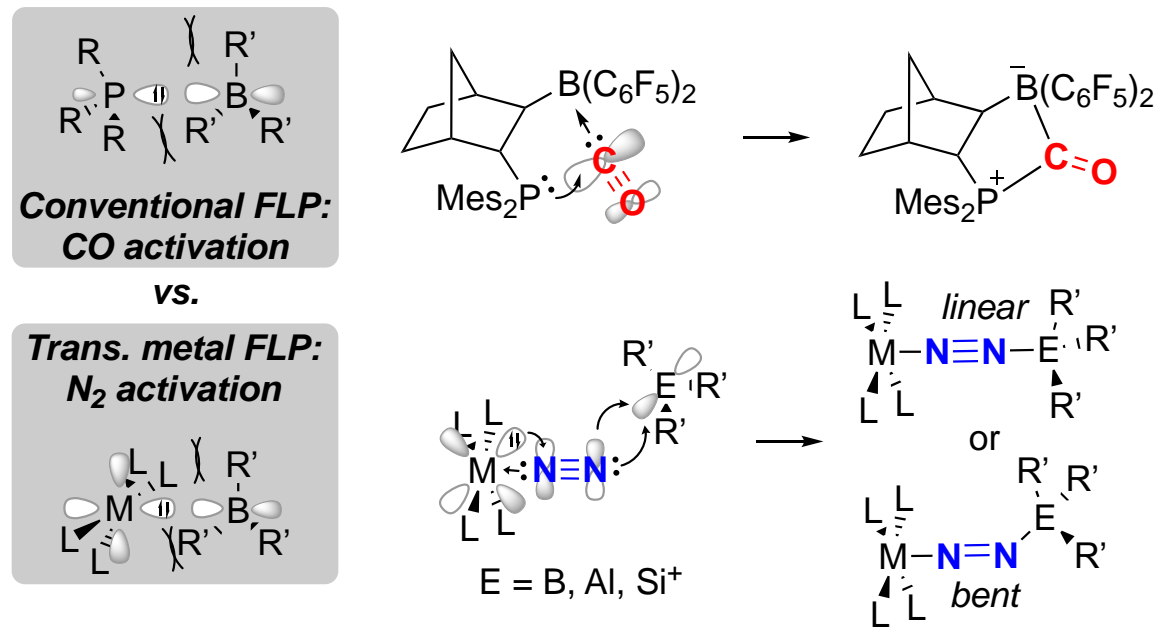

Scheme 5. Comparison of the "conventional" FLP chemistry of isoelectronic CO (top) with the $\mathrm{N}_{2}$ complexes/LA adducts discussed herein, which can be viewed as transition metal FLP templates (bottom).

Although initially based solely on p-block compounds, mixed systems incorporating a metal complex have started to emerge as alternatives to pure main group combinations. ${ }^{[24]}$ The iron dinitrogen complexes/LA combinations of Szymczak and Ashley can be viewed as metal/p-block FLP templates that activate $\mathrm{N}_{2}$, the difference from a conventional FLP being that electron density of the Lewis basic component lies in an orbital of different geometry (see Scheme 5, bottom). The involvement of the metal's filled $d$ orbital in the activation of $N_{2}$ is here the key to make $N_{2}$ amenable to FLP-type chemistry. ${ }^{[25]}$ In conventional phosphorus/boron systems, the P-centered HOMO involved in the small molecule activation cannot build a constructive overlap with the high-lying $N_{2} \pi^{*}$. We recently drew an explicit parallel with this type of $\mathrm{N}_{2}$ activation with FLPs when we reported the Mo and W complexes 12 and 13. ${ }^{[26]}$ Similarly to Szymczak's and Ashley's iron examples, they were prepared from the group 6 dinitrogen complexes 1 and 11 , respectively, by treatment with $B\left(C_{6} F_{5}\right)_{3} .12$ and 13 share a bent NNB arrangement, with a substantially elongated NN bond. This is reflected by the important bathochromic shift of the $v_{\mathrm{NN}}$ in both complexes (-226 and $-236 \mathrm{~cm}^{-1}$, respectively, Scheme 6). Although no calculations were performed on these complexes, it can reasonably be assumed that the same effects explain the activation of the $\mathrm{N}_{2}$ ligand, i.e., enhanced metal-to-ligand charge transfer triggered by LA's interaction with $N_{2}$ 's $\pi^{*}{ }^{[27]}$ One $N_{2}$ ligand is lost upon complexation, as opposed to Chatt's example of the $\mathrm{AlMe}_{3}$ adduct with 1 . $^{[5 \mathrm{~d}]}$ The strong charge transfer caused by the borane may impart a substantial trans influence to the $\mathrm{N}_{2}$ unit, which thus hampers coordination in the second apical site. Compared to the Fe complex 6 , the higher activation of the $\mathrm{N}_{2}$ ligand, as illustrated by $v_{\mathrm{NN}}$ and $\mathrm{N}-\mathrm{N}$ bond lengths, correlates with the greater $\pi$-donating ability of Mo and W. Similar structural and spectroscopic changes are achieved in the Fe complexes of Ashley and co-workers, as a result of the use of the highly electrophilic silylium cation. 

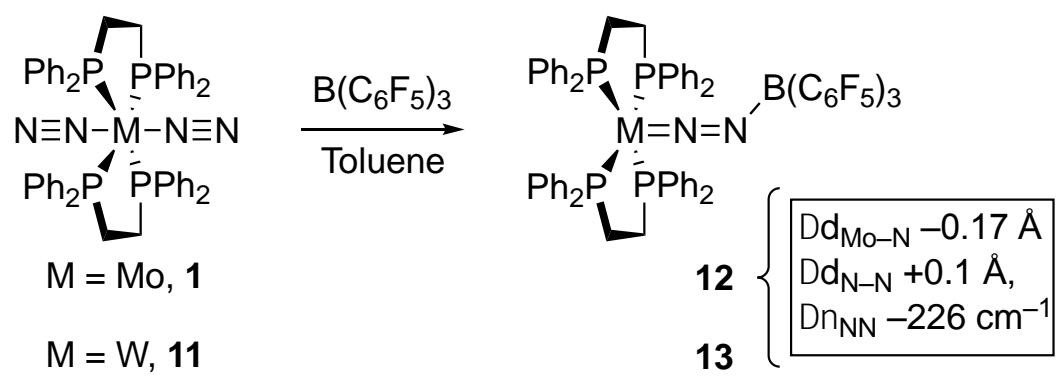

Scheme 6. Adducts of Mo- and $W-N_{2}$ complexes with the strong $L A B\left(C_{6} F_{5}\right)_{3}$.

The Mo and W complexes 12 and 13 were shown to react with hydroboranes and hydrosilanes (Scheme 7). It was postulated that the size of the $\left[(\mathrm{dppe}){ }_{2} \mathrm{M}\left(\mathrm{N}_{2}\right)\right]$ fragment might facilitate dissociation of the borane, which would allow subsequent $\mathrm{B}-\mathrm{H}$ and $\mathrm{Si}-\mathrm{H}$ bond splitting and functionalization of the $\mathrm{N}_{2}$ ligand with boryl and silyl groups in 14-17. Such reactivity again compares well with that of usual nitrogen/boron (N/B) FLPs (Scheme 7, top). ${ }^{[28-30]}$ No borylation or silylation of $\mathrm{N}_{2}$ occurs in the absence of $\mathrm{B}\left(\mathrm{C}_{6} \mathrm{~F}_{5}\right)_{3}$. Akin to 9 and 10, the $\mathrm{N}-\mathrm{N}$ bonds in the functionalized complexes are rather long (1.23-1.27 $\AA$ for the $W$ complexes), with $v_{\mathrm{NN}}$ below $1670 \mathrm{~cm}^{-1}$. These products can be seen as adducts of $d^{6}$ dinitrogen complexes with the elusive $\left[\mathrm{Et}_{3} \mathrm{Si}\right]^{+}\left[\mathrm{HB}\left(\mathrm{C}_{6} \mathrm{~F}_{5}\right)_{3}\right]^{-}$silylium cation, ${ }^{[31]}$ or the unknown $\left[\left(\mathrm{C}_{6} \mathrm{~F}_{5}\right)_{2} \mathrm{~B}\right]^{+}\left[\mathrm{HB}\left(\mathrm{C}_{6} \mathrm{~F}_{5}\right)_{3}\right]^{-}$borinium ion, ${ }^{[32]}$ but we proposed to describe these ionic species 1417 as boryl- or silyl-diazenido complexes with metal centers in the +2 oxidation state. $^{[33]}$ In the silyldiazenido complexes 16 and $\mathbf{1 7}$, the NMR resonances of the ${ }^{29} \mathrm{Si}$ nucleus are shifted to high field, strongly suggesting that the positive charge is not carried by the $\mathrm{Si}$ atom. ${ }^{[34]}$ The actual electronic situation in the group 6 complexes 14-17 remains debatable and calculations are under way to better appreciate it. This should allow detailed comparison with Szymczak's and Ashley's examples.

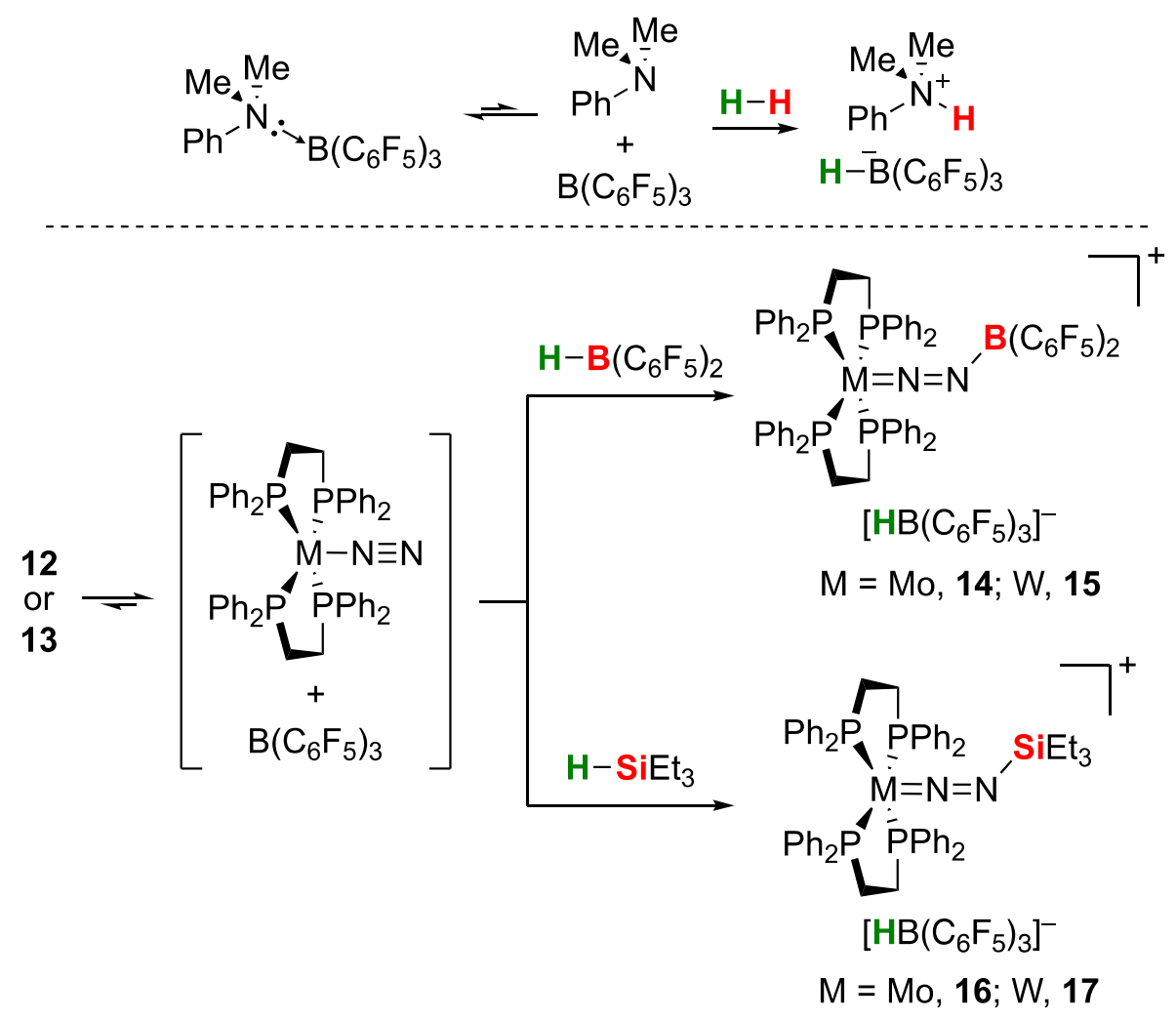

Scheme 7. Conventional nitrogen/boron FLP chemistry (top) compares well with the borylation and silylation of $\mathrm{N}_{2}$ in complexes 12 and 13 (bottom). 
These examples of $\mathrm{B}-\mathrm{H}$ and $\mathrm{Si}-\mathrm{H}$ bond splitting act as an incentive to extend this N/B FLP-type reactivity. We know from Szymczak's and Ashley's work that $\mathrm{d}^{8}$ iron dinitrogen complexes form stable adducts with strong Lewis acids. In-depth studies involving complexes of different metals, ligands and LAs are under way. A deeper understanding of such combinations will allow the design of new FLP templates with tailored properties and reactivity. The chemistry of conventional N/B FLPs is very rich, and its extension to $M-N \equiv N / B$ systems gives a glimpse of new possibilities regarding the functionalization of coordinated $\mathrm{N}_{2}$.

\section{Summary and Outlook}

Since the pioneering work led by the group of Chatt during the 1970s, progress has been made in the understanding of the nitrogenases, and catalytic $\mathrm{N}_{2}$ reductions have been achieved. The field of the Frustrated Lewis pairs has also emerged as a strategy of choice for the activation of small molecules. All these advances of modern chemistry will continue to encourage chemists to give a new look to Lewis acid adducts of (end-on) dinitrogen complexes. This body of recent work clearly demonstrates that combinations of Lewis acids with dinitrogen complexes may develop as a complementary approach for $\mathrm{N}_{2}$ activation and functionalization. A common feature of the examples discussed above is that LA complexation to coordinated $\mathrm{N}_{2}$ lowers the energy level of the HOMO of the $\mathrm{N}_{2}$ complex, a combination of metal-centered $d$ orbitals and $\mathrm{N}_{2}-\Pi^{*}$ orbitals. As a result, important charge transfer takes place from the metal to $\mathrm{N}_{2}$, increasing its polarization. In depth understanding of the bonding situation should help predict the reactivity of such adducts, and gain insights into mechanistic pathways. A challenge associated with this chemistry may reside in the occurrence of electron transfer processes, ${ }^{[6 b, c]}$ as (strong) Lewis acids can also behave as one electron oxidants. ${ }^{[35]}$

\section{References}

[1] A. D. Allen, C. V Senoff, Chem. Commun. 1965, 621-622.

[2] a) J. Chatt, R. L. Richards, J. R. Sanders, J. E. Fergusson, Nature 1969, 221, 551-552; b) J. Chatt, G. A. Heath, R. L. Richards, J. Chem. Soc. Chem. Commun. 1972, 1010-1011; c) J. Chatt, G. A. Heath, R. L. Richards, J. Chem. Soc. Dalt. Trans. 1974, 2074-2082; d) J. Chatt, A. J. Pearman, R. L. Richards, Nature 1975, 253, 39-40; e) M. Hidai, T. Kodama, M. Sato, M. Harakawa, Y. Uchida, Inorg. Chem. 1976, 15, 2694-2697; f) T. Takahashi, Y. Mizobe, M. Sato, Y. Uchida, M. Hidai, J. Am. Chem. Soc. 1980, 102, 7461-7467. g) G. J. Leigh, Acc. Chem. Res. 1992, 25, 177-181.

[3] Recent reviews on nitrogen fixation catalyzed by transition metal complexes: a) N. Stucke, B. M. Flöser, T. Weyrich, F. Tuczek, Eur. J. Inorg. Chem. 2018, DOI: 10.1002/ejic.201701326; b) Y. Roux, C. Duboc, M. Gennari, ChemPhysChem 2017, 18, 2606-2617; c) A. Eizawa, Y. Nishibayashi, Top. Organomet. Chem. 2017, 60, 153-169; d) S. Kuriyama, Y. Nishibayashi, Top. Organomet. Chem. 2017, 60, 215-234.

[4] M. Hidai, Y. Mizobe, Top. Organomet. Chem. 1999, 3, 227-241.

[5] B. M. Hoffman, D. Lukoyanov, Z.-Y. Yang, D. R. Dean, L. C. Seefeldt, Chem. Rev. 2014, 114, 4041-4062.

[6] a) J. Chatt, J. R. Dilworth, R. L. Richards, J. R. Sanders, Nature 1969, 224, 1201-1202; b) J. Chatt, J. R. Dilworth, G. J. Leigh, R. L. Richards, J. Chem. Soc. D Chem. Commun. 1970, 955-956; c) J. Chatt, J. R. Dilworth, H. P. Gunz, G. J. Leigh, J. R. Sanders, J. Chem. Soc. D Chem. Commun. 1970, 90-91; d) J. Chatt, R. C. Fay, R. L. Richards, J. Chem. Soc. A Inorganic, Phys. Theor. 1971, 702-704; e) J. Chatt, R. H. Crabtree, R. L. Richards, J. Chem. Soc. Chem. Commun. 1972, 534; f) J. Chatt, R. H. Crabtree, E. A. Jeffery, R. L. Richards, J. Chem. Soc. Dalt. Trans. 1973, 11671172.

[7] Later, the reactivity of cis-[W( $\left.\left(\mathrm{N}_{2}\right)_{2}\left(\mathrm{PMe}_{2} \mathrm{Ph}\right)_{4}\right]$ towards $\mathrm{ECl}_{3}(\mathrm{E}=\mathrm{Al}$ or $\mathrm{Ga})$ was shown by Hidai and co-workers to afford dimeric complexes of the type $\left[\mathrm{Cl}-\mathrm{WL}_{4}=\mathrm{N}=\mathrm{N}-\mathrm{ECl}_{2}\right]_{2}$ : a) T. Takahashi, T. Kodama, A. Watakabe, Y. Uchida, M. Hidai, J. Am. Chem. Soc. 1983, 105, 1680-1682; b) K. Takagahara, H. Ishino, Y. Ishii, M. Hidai, Chem. Lett. 1998, 897-898. Analogously, the anionic Co complex $\left[\left(\mathrm{Me}_{3} \mathrm{P}\right)_{3} \mathrm{CoN}_{2}\right] \mathrm{K}$ reacts with ClAIMe $e_{2}$ to give the $\left[\left(\mathrm{Me}_{3} \mathrm{P}\right)_{3} \mathrm{Co}=\mathrm{N}=\mathrm{N}-\mathrm{AlMe}\right]_{2}$ dimer and KCl: c) H. F. Klein, K. Ellrich, K. Ackermann, J. Chem. Soc. Chem. Commun. 1983, 888-889. Boryl triflates can also react in a similar manner with $\mathrm{N}_{2}$ complexes, yet without leading to dimeric structures: d) H. Ishino, Y. Ishii, M. Hidai, Chem. Lett. 1998, 27, 677-678.

[8] C. E. Laplaza, C. C. Cummins, Science 1995, 268, 861-863.

[9] D. V Yandulov, R. R. Schrock, Science 2003, 301, 76-78.

[10] a) M. D. Fryzuk, J. B. Love, S. J. Rettig, V. G. Young, Science 1997, 275, 1445-1447; b) J. A. Pool, E. Lobkovsky, P. J. Chirik, Nature 2004, 427, 527-530.

[11] a) S. Gambarotta, J. Scott, Angew. Chem. Int. Ed. 2004, 43, 5298-5308; Angew. Chem. 2004, 116, 5412-5422. For general reviews covering the first 3 decades of the chemistry of $\mathrm{N}_{2}$ complexes, see: b) S. Gambarotta, J. Organomet. 
Chem. 1995, 500, 117-126; c) M. Hidai, Y. Mizobe, Chem. Rev. 1995, 95, 1115-1133; d) J. Chatt, J. R. Dilworth, R. L. Richards, Chem. Rev. 1978, 78, 589-625.

[12] F. Studt, B. A. MacKay, S. A. Johnson, B. O. Patrick, M. D. Fryzuk, F. Tuczek, Chem. Eur. J. 2005, 11, 604-618.

[13] M. D. Fryzuk, Acc. Chem. Res. 2008, 42, 127-133.

[14] F. Studt, B. A. MacKay, M. D. Fryzuk, F. Tuczek, J. Am. Chem. Soc. 2004, 126, 280-290.

[15] J. B. Geri, J. P. Shanahan, N. K. Szymczak, J. Am. Chem. Soc. 2017, 139, 5952-5956.

[16] Measured by their acceptor number, a quantitative parameter calculated from the ${ }^{31} \mathrm{P}$ NMR shifts produced in triethylphosphine oxide upon coordination of the LA: M. A. Beckett, G. C. Strickland, J. R. Holland, K. S. Varma, Polymer 1996, 37, 4629-4631.

[17] Reviews dealing with Fe-catalyzed $\mathrm{N}_{2}$ reductions: a) K. C. MacLeod, P. L. Holland, Nat. Chem. 2013, 5, 559-565; b) N. Hazari, Chem. Soc. Rev. 2010, 39, 4044-4056.

[18] A. D. Piascik, P. J. Hill, A. D. Crawford, L. R. Doyle, J. C. Green, A. E. Ashley, Chem. Commun. 2017, 53, 7657-7660.

[19] $\mathrm{N}_{2}$ reductions to silylamines catalyzed by Fe complexes: a) M. Yuki, H. Tanaka, K. Sasaki, Y. Miyake, K. Yoshizawa, Y. Nishibayashi, Nat. Commun. 2012, 3, 1254; b) R. Araake, K. Sakadani, M. Tada, Y. Sakai, Y. Ohki, J. Am. Chem. Soc. 2017, 139, 5596-5606; c) R. Imayoshi, K. Nakajima, J. Takaya, N. Iwasawa, Y. Nishibayashi, Eur. J. Inorg. Chem. 2017, 2017, 3769-3778; e) D. E. Prokopchuk, E. S. Wiedner, E. D. Walter, C. V Popescu, N. A. Piro, W. S. Kassel, R. M. Bullock, M. T. Mock, J. Am. Chem. Soc. 2017, 139, 9291-9301.

[20] Examples of such silyldiazenido and/or disilylhydrazido Fe complexes: a) T. A. Betley, J. C. Peters, J. Am. Chem. Soc. 2003, 125, 10782-10783; b) Y. Lee, N. P. Mankad, J. C. Peters, Nat. Chem. 2010, 2, 558-565; c) P. A. Rudd, N. Planas, E. Bill, L. Gagliardi, C. C. Lu, Eur. J. Inorg. Chem. 2013, 2013, 3898-3906; d) G. Ung, J. C. Peters, Angew. Chem. Int. Ed. 2015, 54, 532-535; Angew. Chem. 2015, 127, 542-545.

[21] To avoid digression and keep up with the topic of this article, we choose to limit the discussion to Ashley's example, as the way their Fe complex forms can actually be seen as a $\mathrm{Me}_{3} \mathrm{Si}^{+}$cation interacting with an $\mathrm{N}_{2}$ ligand, thus forming a cationic Lewis pair.

[22] a) D. W. Stephan, Science 2016, https://doi.org/10.1126/science. aaf7229; b) D. W. Stephan, G. Erker, Angew. Chem. Int. Ed. 2015, 54, 6400-6441; Angew. Chem. 2015, 127, 6498-6541; c) D. W. Stephan, G. Erker, Angew. Chem. Int. Ed. 2010, 49, 46-76; Angew. Chem. 2010, 122, 50-81.

[23] M. Sajid, A. Lawzer, W. Dong, C. Rosorius, W. Sander, B. Schirmer, S. Grimme, C. G. Daniliuc, G. Kehr, G. Erker, J. Am. Chem. Soc. 2013, 135, 18567-18574.

[24] a) S. R. Flynn, D. F. Wass, ACS Catal. 2013, 3, 2574-2581. b) D. F. Wass, A. M. Chapman, Top. Curr. Chem. 2013, 334, 261-280.

[25] While this article was being written, Stephan and co-workers reported the isolation of the adduct of diazodiphenylmethane with $\mathrm{B}\left(\mathrm{C}_{6} \mathrm{~F}_{5}\right)_{3}, \mathrm{Ph}_{2} \mathrm{C}=\mathrm{N}=\mathrm{N}-\mathrm{B}\left(\mathrm{C}_{6} \mathrm{~F}_{5}\right)_{3}$. A prelude to the FLP chemistry of $\mathrm{N}_{2}$ with pure main group system is thus composed: a) C. Tang, Q. Liang, A. R. Jupp, T. C. Johnstone, R. C. Neu, D. Song, S. Grimme, D. W. Stephan, Angew. Chem. Int. Ed. 2017, 56, 16588-16592; Angew. Chem. 2017, 129, 16815-16819. This FLP-type activation of $\mathrm{N}_{2}$ was subsequently highlighted by Melen: b) R. Melen, Angew. Chem. Int. Ed. 2017, 56, 880-882; Angew. Chem. 2017, 129, 890-892.

[26] A. Simonneau, R. Turrel, L. Vendier, M. Etienne, Angew. Chem. Int. Ed. 2017, 56, 12268-12272; Angew. Chem. 2017, $129,12436-12440$

[27] Although the Fe complexes 6, 9 and 10 on the one hand and the Mo and W complexes 12 and 13 on the other hand do not share the same geometries, the orbital involved in the back-bonding are in every case a set of two symmetrydegenerated $d_{x y}, d_{x z}$ or $d_{y z}$ orbitals. This allows, to some extent, comparison of the bonding situations in these different species.

[28] Formation of a classical $\left(\mathrm{C}_{6} \mathrm{~F}_{5}\right)_{3} \mathrm{~B} \cdot \mathrm{NR}_{3}$ adduct does not preclude a FLP behavior: a) T. Voss, T. Mahdi, E. Otten, R. Fröhlich, G. Kehr, D. W. Stephan, G. Erker, Organometallics 2012, 31, 2367-2378; b) T. C. Johnstone, G. N. J. H. Wee, D. W. Stephan, Angew. Chem. Int. Ed. 2018, 57, 5881-5884. For a review dealing specifically with B/N FLPs, see: c) V. Sumerin, K. Chernichenko, F. Schulz, M. Leskelä, B. Rieger, T. Repo, Top. Curr. Chem. 2013, 332, 111-155.

[29] B-H bond activation with FLPs: M. A. Dureen, A. Lough, T. M. Gilbert, D. W. Stephan, Chem. Commun. 2008, 43034305.

[30] Si-H bond activation with FLPs: a) D. Chen, V. Leich, F. Pan, J. Klankermayer, Chem. Eur. J. 2012, 18, 5184-5187; b) W. Nie, H. F. T. Klare, M. Oestreich, R. Fröhlich, G. Kehr, G. Erker, Z. Naturforsch. B 2012, 67, 987-994; c) S. Tamke, C.G. Daniliuc, J. Paradies, Org. Biomol. Chem. 2014, 12, 9139-9144; d) A. Gudz, P. R. Payne, M. R. Gagné, Organometallics 2017, 36, 4047-4053.

[31] a) S. Rendler, M. Oestreich, Angew. Chem. Int. Ed. 2008, 47, 5997-6000; Angew. Chem. 2008, 120, 6086-6089; b) A. Y. Houghton, J. Hurmalainen, A. Mansikkamäki, W. E. Piers, H. M. Tuononen, Nat. Chem. 2014, 6, 983-988.

[32] Y. Shoji, N. Tanaka, K. Mikami, M. Uchiyama, T. Fukushima, Nat. Chem. 2014, 6, 498-503.

[33] Examples of related complexes: ref. 7d; a) K. Komori, S. Sugiura, Y. Mizobe, M. Yamada, M. Hidai, Bull. Chem. Soc. Jpn. 1989, 62, 2953-2959; b) M. Hidai, K. Komori, T. Kodama, D.-M. Jin, T. Takahashi, S. Sugiura, Y. Uchida, Y. Mizobe, J. Organomet. Chem. 1984, 272, 155-167.

[34] As opposed to the adducts of $\mathrm{Me}_{3} \mathrm{Si}^{+}$with tertiary amines where ${ }^{29} \mathrm{Si} \mathrm{NMR}$ suggests partial localization of the positive charge at Si: a) G. A. Olah, L. D. Field, Organometallics 1982, 1, 1485-1487; b) M. Arshadi, D. Johnels, U. Edlund, C.-H. Ottosson, D. Cremer, J. Am. Chem. Soc. 1996, 118, 5120-5131; c) Y. Zhang, F. Lay, P. García-García, B. List, E. Y. -X. Chen, Chem. Eur. J. 2010, 16, 10462-10473; d) M. Rohde, L. O. Müller, D. Himmel, H. Scherer, I. Krossing, Chem. Eur. J. 2014, 20, 1218-1222. 
[35] As an example, this behavior was sporadically reported for $\mathrm{B}\left(\mathrm{C}_{6} \mathrm{~F}_{5}\right)_{3}$ : C. J. Harlan, T. Hascall, E. Fujita, J. R. Norton, J. Am. Chem. Soc. 1999, 121, 7274-7275. 